There are a few small additions to the original French version published by Gauthier-Villars, notably Kouchnirenko's work on A-entropy and Katok-Stepin's work on periodic approximations. The reader should be wary about minor mistakes-for example, exercise 4.4 mentions an open conjugacy problem which is trivially solvable by a linear map, and the reference to Sinai on page 43 applies to Bernoulli transformations and not to torus automorphisms.

William ParRy

\section{ADVICE FOR TEACHERS}

\section{How to Teach Mathematics in Secondary Schools}

By Herbert Fremont. (Saunders Science Teaching Series.) 1.p. xv+571. (W. B. Saunders: Philadelphia and London, February 1969.) $89 s$.

THis book does not set out to tell teachers of mathematics how to teceh mathemstics, is the title implies, but contains instoed a serics of suggestions and advice on method to teachers. Although written with the American teacher clearly in mind, it makes reference to modern trends in other countries, and conteins much of value for mathematics teachers in English schools. It is as much a useful reference book for those involved in traditional approaches to mathematics as to those using experimental methods, because it is not confined to the content of any specific syllabus, nor to the needs of any specific examination. One very valuable feature of the book is the fact that it is not written with any particular type of child in mind-there are sections dealing with suggested approaches to the "low achiever" and to the "gifted". There are suggestions for class teaching, for group teaching and for individual instruction.

After an excellent section dealing with the nature of mathematics and the history of mathematies education, plans of instruction and methods of learning, Professor Fremont spends some time considering the actual mathematics for pupils in secondary schools. The mathematical content of the book is well presented, and is tackled in some detail-the mathematical topics covered being arranged in four sections. The "Before Algebra" section deals with arithmetic, statistics and informal geometry and a survey of some modern topies. In the algebra and geometry sections the content of traditional syllabuses is investigated in some depth. The mathematics of the book finishes with a section appropriate to the upper part of a secondary school, in which the calculus, analytical geometry and trigonometry are considered.

It is, on the whole, fairly traditional in its approach to most topics, in that it presents the theory (often stated as a theorem) followed by worked problems. There are novel and experimental ideas in some sections, however, where the teacher is encouraged to teach from the experience of the child. It is particularly worth mention that the sections on informal geometry and on statistics are tackled from this standpoint. Fremont advocates looking at shapes and data which are familiar to the child and encourages the teacher and his pupils to investigate the mathematics which evolves. The chapters conclude with extensive bibliographies of books and periodicals, and excellent sets of ideas "for investigation and discussion". These ideas are of a pedagogic nature rather than specific mathematical exercises.

This is a book which should be studied critically by any serious teacher of mathematics and by teachers in training; it contains a host of ideas and suggestions, and tries to show briefly the aims of each topic. To quote the author's epilogue, it is hoped that teachers will "move out on their own and create more challenging and meaningful experiences for students than have found their way between these covers".

DAVID C. TAYLOR

\section{Obituaries}

\section{Professor Alun Roberts}

Professor Robert Alun Roberts, who dicd on May 15, aged 75, was the first Professor of Agricultural Botany at University College, Bangor. A native of the upper Nant tle valley, Caernervonshire, he graduated in 1915 with honours in botany at Bingor, under the late Professor Reginald W. Phillips. Afur a brief period school teaching in South Caernarvonshire, Alun Roberts was appointed an adviser in agricultural botany in 1919 and a lecturer in 1920. He remained associated with the Department of Agricultural Botany, becoming independent lecturer in 1925 and professor from 1945 until his retirement in 1960.

His drive, initiative and scholarship produced al department which was given univers ity status in 1926 and which for many years afterwards offered a unique joint honours course with its sister Department of Botany. Herein perhaps lies Roberts's great contribution to university edueation. Almost single handed, he developed a three year course in agricultural botany which maintained a high standard of learning equivalent to other scienee departments in the college and which offered full honours degrees within the university.

Although heavily involved with departmental duties, Alun Roberts did not forgo his research activities. Ho quickly took advantage of the facilities which the environs of Bangor offered for plant ecology. His first major work was an agronomic and ccological survey of the Lleyn Peninsula which was later extended to cover Caernarvonshire. His other rescarches involved the correlation of grain yields in oets with local meteorological data and the significance of variety in respect to yield and other ancillary characters.

Roberts also directed his postgraduate student assistants in a diversity of researches. These included the formation of pastures in North Wales, the effects of shoot cutting on the growth of grasses, the effects of various manures on the yield of hay and botanical composition of the herbage of meadows. As a result of these detailed studies Alun Roberts became an active member of the Pasture Analysis Sub-Committee of the Agricultural Education Association set up in 1929 to assess the relative merits of the different methods of analysis. This led him to investigate the composition of old pasture of high repute in North Wales-a study which had considerable significance and benefit at the time.

After his secondment on county executive work during the Second World War, Alun Roberts returned to Bangor and his early experiences proved invaluable in the post war expansion of the department. His own researches were now extended to the problems of the ecology of human occupation and land use in Snowdonia. He was soon recognized as an outstanding figure with an unparalleled knowledge of the scientific, coupled with the historical and sociological aspects of land use, and he published widely. His experience was eagerly sought on the Agricultural Land Commission Welsh Sub-Committee and the Royal Commission on Common Lands. He became the first chairman of the Welsh Committee of the Nature Conservancy and was an active member of the Forestry Commission for Wales.

Most of his retirement was spent on a survey of the Common Land of England and Wales and he was the joint author of "Commons and Village Greens, a Study in Land Use, Conservation and Management, based on a National Survey of Commons in England and Wales 1961-1966".

Alun Roberts lectured and broadcast frequently and had a wide knowledge of the Welsh countryside. He delivered the O'Donnell Lectures in the University of Wales 195455. He was High Sheriff of Caernarvonshire in 1955-56 and his university was to have honoured him with the degree of DSc next July. 